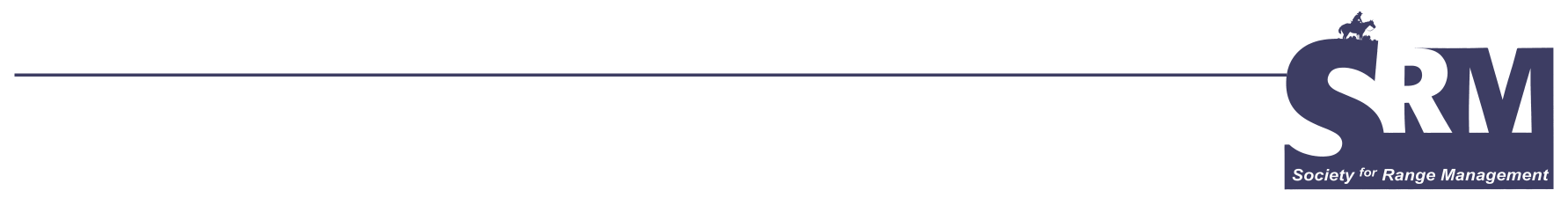

\title{
In Public Land Ranching Is the Preservation of Western Landscapes
}

\section{By Jeffrey O. Durrant}

In wildness is the preservation of the world.

- Henry David Thoreau

I

n an essay titled "Thinking Like a Mountain," former US Forest Service employee and conservation icon Aldo Leopold expresses regret for standing on a rimrock in New Mexico years earlier and gunning down a mother wolf and her cubs. He laments that he didn't know then what he believes the mountain always understoodthat the mountain needed the wolf as much as the wolf needed the mountain. Without the wolf, mountain slopes became crisscrossed with deer trails and vegetation-denuded. Or as Leopold put it, "I now suspect that just as a deer herd lives in mortal fear of its wolves, so does a mountain live in mortal fear of its deer." ${ }^{1}$ Although wolves soon disappeared from the West, the notion of "thinking like a mountain" took root. Today "ecosystem" science is the rage; we talk of species and habitat interconnectedness and the need to take a holistic approach that includes the entire ecosystem-a mind-set that, among other things, led to wolf reintroduction in Yellowstone.

Current US Forest Service Chief Dale Bosworth has stated, "perhaps the most important thing we've learned is just how complex and interdependent ecosystems are." The ecosystem approach has brought with it a new set of terms, among them the concept of "indicator species." As much as scientists interested in ecosystems would like to gather detailed data on numerous species, it isn't practical over large areas such as the West's vast public lands. So certain species are looked at as "indicators" of the health or proper function of an ecosystem. A central premise of indicator species is that their decline may indicate a disturbance that alters the ecosystem.

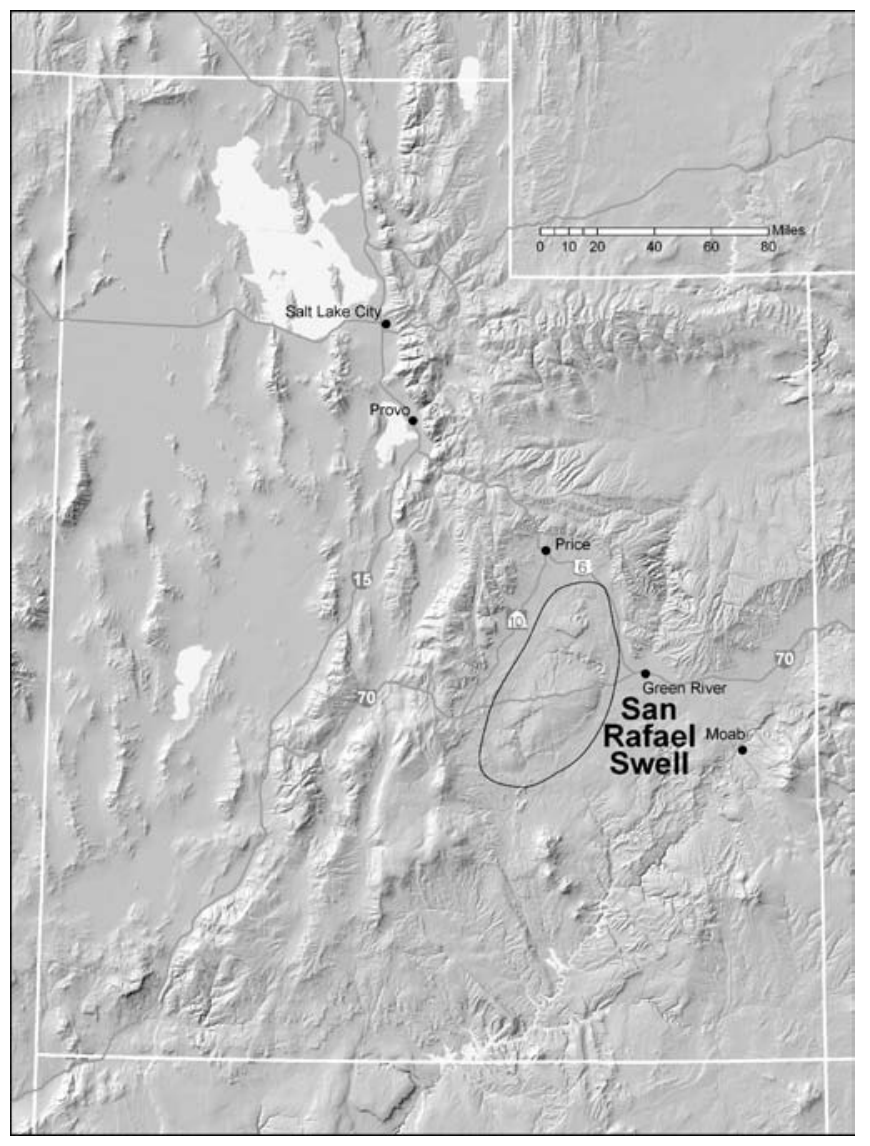

Public land ranchers are not candidates for endangered species listing and are not considered a critical ecological indicator. But they are under stress and, in some areas, fad- 


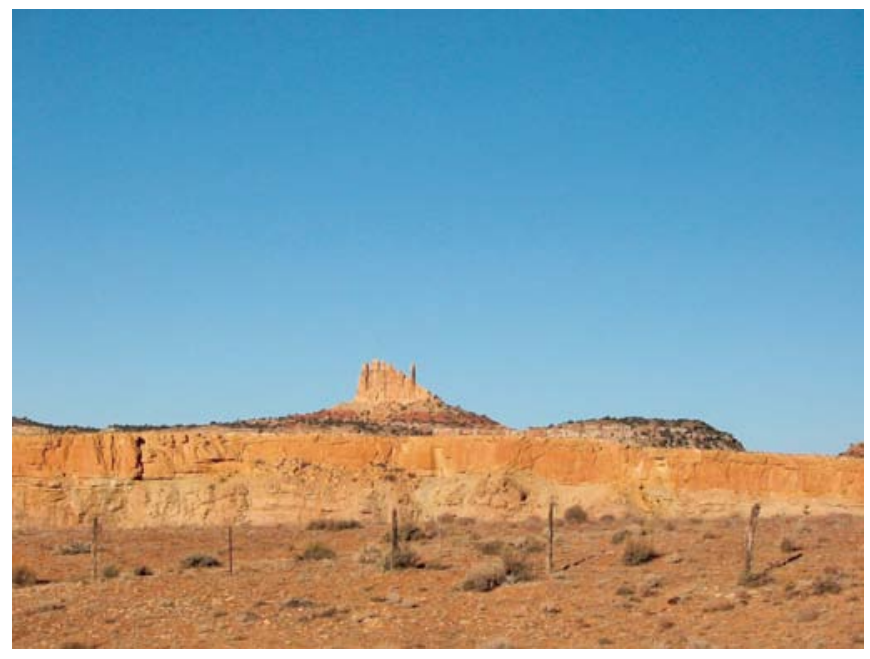

ing away. Some may view this trend as a tragedy, others as a good thing. But for me, the real calamity would be in wiping out public land ranching without deep consideration of what that would mean for Western landscapes, and so, perhaps, some contemplation of them as an indicator of the trend of Western landscapes would be useful. Analogies are easily stretched thin, but they can help us carefully consider our course of action and, hopefully, provoke deeper responses and thoughtfulness. I believe we should consider carefully the future of public land ranching. Would it matter if we got rid of public land ranchers, whether by outright decree or making operations progressively more difficult until they give up? What would their demise signify about the future of Western landscapes?

\section{A Ranching Landscape}

Utah's San Rafael Swell is a million-acre upthrust of federal public land that, like much of southeastern Utah, has been carved and shaped by harsh biophysical processes into sandstone pinnacles, buttes, cliffs, washes, slot canyons, and slickrock domes. Intermixed with the spectacular, red rock formations that draw increasing numbers of climbers, hikers, campers, sightseers, and other recreationalists are rangelands where livestock have grazed since the late 1800s. Today's ranchers live in the small communities of Castle Valley to the west of the "Swell," although several ancestors' efforts to homestead the Swell are still evident in remote rustic cabins and the numerous place names that memorialize the more colorful early cowboys.

Today's San Rafael ranchers drive motorized vehicles on bumpy dirt roads that, more often than not, are a partial legacy of the uranium frenzies of the 20th century. Mixed in with the abandoned mines and decaying heavy equipment are world-class technical rock climbing areas, stock ponds, rock art sites, grazing allotment fences, and sagging gates. In recent years, Wilderness Study Area (WSA) i signs have blossomed, and most San Rafael grazing allotments intersect with this relatively new management designation. Multiple interviews with ranchers operating in the San Rafael Swell clearly show a plethora of views and operational adjustments resulting from interaction with WSA management policy.

The San Rafael Swell has plenty of wilderness - as one San Rafael rancher insisted, "This has been wilderness out here forever." The large "W" Wilderness, or a formal congressional designation, is another matter. On BLM land, Utah has very little, and the San Rafael Swell has none; yet, the ongoing struggle over potential BLM Wilderness designation in Utah is arguably one of the West's most contentious public land struggles.

The BLM has historically been caricatured as the "forgotten" agency or the managers of "leftover" lands nobody wanted. This characterization, although increasingly inaccurate, is readily apparent in early Wilderness advocacy efforts. The Wilderness Act of 1964 does not even mention the BLM ${ }^{\mathrm{iii}}$ but instead directs the other federal land management agencies to inventory their lands for possible Wilderness designation. Initial Wilderness designations, including the 9 million acres designated with the passage of the Wilderness Act, were primarily focused on relatively high-altitude rock and ice-far not only from BLM lands but also from the commodity-producing areas of other federal lands. With the passage of the Federal Lands Policy and Management Act (FLPMA) in 1976, Congress not only solidified the policy that BLM lands would be kept under federal control but determined that these lands should also be inventoried for possible Wilderness designation. In short, the forgotten lands had been found by the Wilderness movement.

In the early 1980s, the BLM conducted their first statewide review in Utah of lands possessing "Wilderness characteristics." The review process resulted in the designation of 3.2 million acres of WSAs, including 6 WSAs totaling over 260,000 acres in the San Rafael Swell. As with many federal land management agency actions, not very many people were satisfied with the outcome of the BLM process. Many individuals, often led by vocal rural political leaders, were unhappy that so much land had been "locked up." On the other side, the emerging Utah Wilderness Coalition (UWC) and like-minded supporters believed

\footnotetext{
${ }^{\mathrm{i}}$ WSAs are designated by the BLM and managed to preserve the area "wilderness characteristics" until Congress (who has sole authority for Wilderness designation) acts to formally designate an area as Wilderness or release the area for other uses.

ii Quotes from San Rafael ranchers used in this essay are from a multiyear research project on ranching in the San Rafael Swell. For methodological detail, see Dods, N. 2003. The impact of wilderness study areas on the livelihood and way-of-life of ranchers in the San Rafael Swell [MS thesis]. Provo, UT: Department of Geography, Brigham Young University.

iii In large part, since in 1964, national policy was uncertain whether these lands should even remain in the public domain.
} 
strongly that far more land should have received special designation. The UWC, led by the Southern Utah Wilderness Alliance (SUWA), conducted their own inventory and soon began aggressively promoting a proposal for 5.7 million acres of BLM Wilderness in Utah-including a substantial increase in the San Rafael Swell region. During the 1990s, both the BLM and the UWC conducted new Wilderness reviews in Utah. The BLM re-review found many additional areas outside of existing WSAs that possessed "Wilderness character," and the UWC enlarged their proposal (which over the years had been accumulating cosponsors in Congress) to more than 9 million acres. The latest UWC proposal would designate approximately 1 million acres of Wilderness in and adjacent to the San Rafael.

\section{The Rancher's View?}

Overall, attitudes toward WSA designation and management among San Rafael ranchers are very similar to the general public in southeastern Utah-some like it, some have mixed views, and many don't like it at all. ${ }^{3}$ Many ranchers express opinions in general terms such as, "Wilderness designation would change the land use of the San Rafael Swell. I would hate to see any country go to Wilderness." However, most negative feelings toward Wilderness designation by San Rafael ranchers do not emanate from a blustery and broad philosophy but rather from specific experiences with WSA management and their belief that WSA status makes difficult ranching operations even more so- to the point of making public land ranching plainly "impractical." Top among the gripes of ranchers whose allotments in the San Rafael Swell overlap, to some extent, existing WSAs are restricted motorized access, closer scrutiny, increasing bureaucracy, and a decreasing voice in policy decision and implementation.

I can ride on my 4-wheeler and ride with common sense and see my cows in a matter of hours. It would take me 2 days on a horse... Let's wake up and join the twentieth century! - Jessie May Winder, San Rafael rancher

Most rangeland is in the center of the San Rafael Swell, ringed by a remarkable jumble of red rock formations, and cattle have a bad habit of not sticking to the main roadsunderstandably, ranchers prefer the motorized option in tracking them down. Their ancestors may have relied on horses and wagons, but they would prefer not to do the same. They must also maintain fences and gates, and despite the arid nature of the Swell, an occasional storm through the area is likely to wash out stock ponds. Here again, ranchers prefer bringing in a backhoe rather than walking in with a few shovel-wielding friends.

What I'm worried about with Wilderness designation is too much red tape involved in grazing, too many forms to fill out. It's just a bunch of bureaucracy. There's plenty of

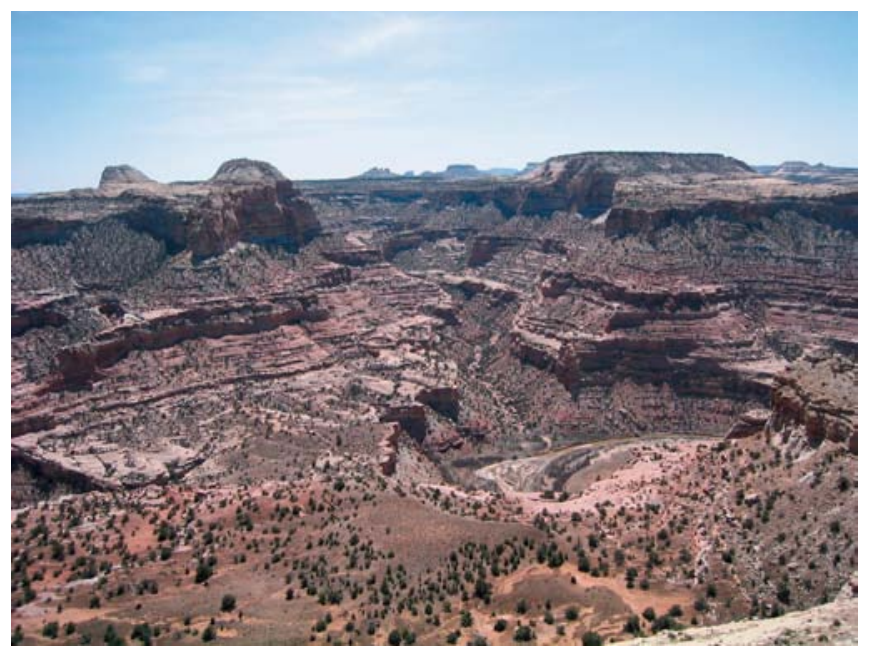

that now-a lot of paper work. -Kash Winn, San Rafael rancher

Increasing oversight and heavier management of grazing operations has been an ongoing legacy for ranchers for most of a century. In addition to enhanced expectations by the public, WSA status has added another set of guidelines to the area's management. San Rafael ranchers are apt to see the BLM as much more demanding and the general public as increasingly intolerant with their livelihoods.

Here a few years ago out on the Wedge, I had to haul some cows out of that canyon. We go down there the 1st of May. Anyway, we were gathering some cows down there in Red Canyon, and this guy and gal come up on their bikes-their mountain bikes. This little gal got onto me about how them cows were down there in that nice pristine country, you know, and all these cow pies all over. And I went on explaining to her that we went down there the 1st of November; we've got to have them out the 15th of April, which normally there ain't nobody in that country, and if you've been down there it's an ungodly place. She went on and on how disgusting it was and everything to have these cows out there. And I was getting a little bit upset with her. And I asked her, I says, "Ma'am, was that your van I seen parked up there by the trail by the bulge?"

She says "Yeah."

"Hell, I seen a barbecue out by there."

She says "Yeah."

"Well, what are you going to put on that barbecue tonight?" I says, "You're going to put a hamburger on there, or a steak, or what are you gonna put on there?" 
"Yeah, we're going to cook up some hamburgers when we're done riding."

And I said, "Where in the hell do you think that beef comes from? If it ain't for people like us running cows down here in this country, in the wintertime, when 5 years ago you people didn't even know it existed." I says, "You think that just comes out of the store?"

Then her husband grabs her by the arm and says, "Honey let's go." And they left.

Well, where does it come from? People don't have no comprehension. - Jessie May Winder, San Rafael rancher

Irate mountain bikers are not the only new players that public land ranchers must deal with-they see a number of new players who are demanding a say in public land management. Consequently, ranchers see their own voice diminishing. Many of the new voices are particularly concerned about Wilderness and WSAs. They want these areas managed in a way that they see as appropriate. They want sunsets and red rock, not filthy cattle. Organized environmental groups are seen by the ranchers as the biggest threat to their influence of local BLM managers.

You got a handful of people that calls themselves environmentalists that I'm sure a fair share of them got a rich daddy that gives them money to keep them out of their hair, and they got nothing else to do but cause trouble. They think they're saving the world. - Ross Hinkins, San Rafael rancher

San Rafael ranchers are not just upset about a new player in town with a different agenda, but also how these groups portray public land ranching. They fear that they can't compete for public good will when environmental groups are aggressively portraying them as "dirty cattlemen" who are destroying vast swaths of country.

San Rafael ranchers certainly see an impact, generally negative, of WSA designation and management on their grazing operations-but this is not all they see. It is a sobering reality for many ranchers that the impacts of WSAs are in many ways amplifications of broader trends in public land management and the livestock industry. For decades, ranchers held the upper hand in public land grazing policyindeed some have argued that they held too much sway. But the pendulum has begun slowly shifting during the past 2 decades. ${ }^{4}$ They are often quite aware and even outspoken about the broader cultural, economic, and political changes occurring around them and how these changes are affecting rural communities. For instance, the "New West" is characterized by booming industries in recreation and tourism whereas mining, grazing, and logging sag into decline. ${ }^{5}$
There has been a continuous cycle of up and down as far as cattle and livestock prices. Right now, they're high. I can remember a few years back they were way low. That cycle has repeated itself probably 6 or 7 times that I can remember. And to be honest with you I think it's awfully hard to make a living in the livestock business unless you're a corporate giant-some major corporation, something big. -Kash Winn, San Rafael rancher

There's still probably quite a few hobby ranchers, but probably not near as many as there used to be. Back when I was younger, there were only 3 things you could do in this county - that was coal mine or teach school or be a rancher. Since then, it has sort of diversified. We've got the power plants now. We've been hearing more and more about more power plants coming in, and the railroad coming in, and that will definitely impact the lifestyle. I've got mixed emotions about that. I don't know if that needs to be ... -Archie Lee Jeffs, San Rafael rancher.

The result of these changes and uncertainties is that ranching, a difficult enterprise in the best of circumstances, is less profitable financially, and there is more anxiety about the future in ranching households. Wilderness designations, San Rafael ranchers appear to realize, only accelerate these changes - or make a possible outcome increasingly probable.

\section{Conserving Western Landscapes}

If we want to understand ourselves, We would do well to take a searching look at our landscapes-D. W. Meinig ${ }^{6}$

"Landscape" is an elusive term. Even the renowned geographer J. B. Jackson, who spent the better part of his career pursuing the idea, admitted "that the concept continues to elude me." In June 2000, Secretary of the Interior Bruce Babbitt used the term when he created a National Landscape

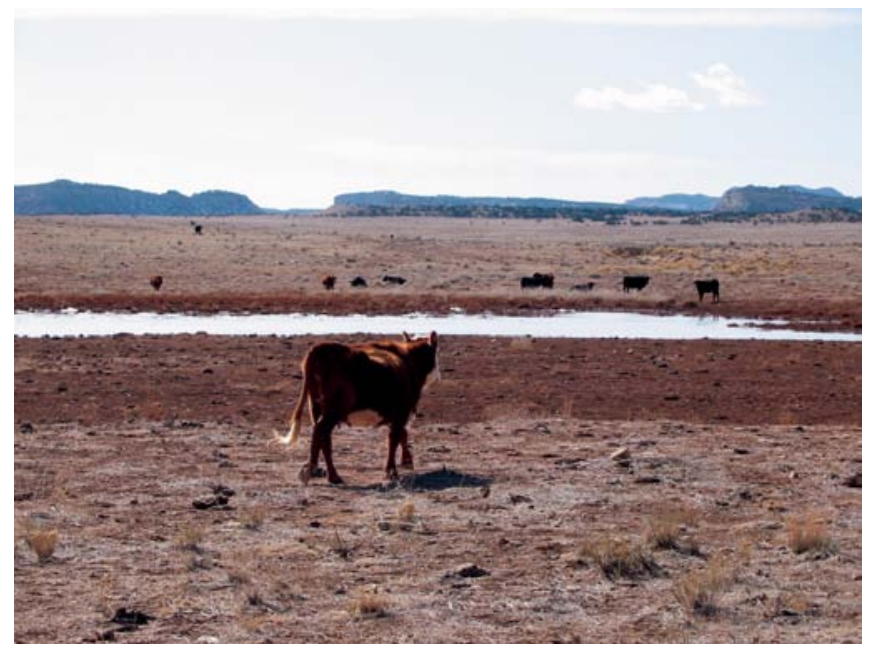


Conservation System (NLCS), consisting of BLM National Monuments, National Conservation Areas, Wilderness Areas, and other protective area designations. Only 4 years earlier, Secretary Babbitt was instrumental in advising President Bill Clinton to designate the Grand Staircase-Escalante National Monument in southern Utah as the first BLM-administered National Monument. In creating the NLCS, Babbitt was hoping "that, by endowing the BLM with a high-profile conservation mission, the old bureaucratic mule will awaken to a new future as environmental steward right up there with National Park Service." Babbitt's motivation stemmed from his belief that "the characteristic BLM lands are the essential, defining landscapes of the American West." ${ }^{\prime}$ It is easy to agree with his sentiments, but his conception of a landscape is less inviting. Babbitt's notion of landscape at times appears to magnify "nature" and ignore or minimize what a landscape, even in its broad and ambiguous use, most often represents - the interaction of humans and their environment. BLM landscapes are certainly cultural landscapes - they may not have many houses, office buildings, plowed fields, supermarkets, and schools, but they are chock-full of stock ponds, fences, climbing anchors, old cabins, mine shafts, hiking trails, scenic pullouts, and other evidence of a dynamic landscape shaped by past and ongoing human interaction. BLM landscapes are magnificent landscapes, and if we radically alter them, will we also lose a sense of the American West? And do the cow and rancher play an integral part?

Conserving dynamic landscapes is a tricky business, especially if we want to conserve what we see but not what created it. If BLM landscapes are the quintessential Western landscape, then public land ranching would be a primary architect. For better or worse, ranching has been around on these lands for over a century. Many areas with and without Wilderness characteristics are, in part, a product of ranching.

When a biological species is wiped out, or like the California Condor brought near extinction, I believe it is important. But what may be even more critical is how and why we wiped out or nearly wiped them out. And what that portends for the future of the ecosystem. What does it indicate about the past, present, and future condition?

I personally do not believe it is critical or even desirable to maintain public land ranching at the levels we have in the past, but I believe we should be concerned about how and why we would get rid of it. Does the BLM have a different conservation model as Secretary Babbitt hoped? Or is it just a lower-budget application of the National Park Service? If stock ponds, miles of barbed wire fencing, old gates for passengers to open, water tanks, and livestock themselves disappear from the landscape, what will replace them? Nothing? A return to native vegetation cover? Or will it be more information kiosks, curbed and guttered scenic pullouts, visitor centers and well-coifed federal employees, regulated hiking trails, expert-led interpretive field trips, and a forest of restrictive signs?

Do these landscapes know something that we have yet to realize? Will the absence of traditional public land uses, such as ranching, create mountains and rangelands different from that which we are trying to conserve? If the mountain didn't fear the howl of a wolf, should we feel we're in mortal danger from the bawl of a calf?

Author is Assistant Professor, Department of Geography, Brigham Young University, Provo, UT 84602, jodurrant@byu.edu.

\section{References}

1. LeOpold, A. 1949. A sand county almanac. Oxford and London: University of Oxford Press. p. 132.

2. BosworTh, D. 2003. Changing the debate on managing national forests and grasslands. Society of Environmental Journalists annual conference; 12 September; New Orleans, LA. Washington, DC: US Forest Service.

3. Durrant, J. O., And J. M. Shumway. 2004. Public attitudes towards Wilderness Study Area designation and use in southeastern Utah. Environmental Management 33(2):271-283.

4. Davis, C. 2001. Politics and public rangeland policy. In: C. Davis [ed.]. Western public lands and environmental politics. Boulder, CO: Westview Press.

5. HaVlick, D. G. 2002. No place distant: Roads and motorized recreation on America's public lands. Washington, DC: Island Press. p 138.

6. Meinig, D. W. 1979. The interpretation of ordinary landscapes: Geographical essays. New York and Oxford: Oxford University Press. p 2.

7. JaCKSON, J. B. 1979. The order of landscape: reason and religion in Newtonian America. In: D. W. Meinig [ed.]. The interpretation of ordinary landscapes: Geographical essays. New York and Oxford: Oxford University Press. p 153.

8. BabBitT, B. 2003. The heart of the West: BLM's National Landscape Conservation System. In: M. P. Dombeck, C. A. Wood, and J. E. Williams [eds.]. From conquest to conservation: Our public lands legacy. Washington, DC: Island Press. $\mathrm{p}$ 100-102. 